\title{
Effects of land use on concentrations of metals in surface soils and ecological risk around Guanting Reservoir, China
}

\author{
Wei Luo $\cdot$ Yonglong Lu · John P. Giesy · Tieyu Wang • \\ Yajuan Shi · Guang Wang · Ying Xing
}

Received: 27 March 2007 / Revised: 1 July 2007 / Accepted: 11 July 2007 / Published online: 6 September 2007

(C) Springer Science+Business Media B.V. 2007

\begin{abstract}
It is accepted that the historical routine use of agrochemicals may have resulted in undesirable concentrations of metals in the environment. To investigate and assess the effects of land use on concentrations of heavy metals around the Guanting Reservoir in China, 52 surface soil samples (depth of $2-10 \mathrm{~cm}$ ) were taken from areas where four types of land use were practiced (including arable land, woodland, bare land, orchard land). The metals and metalloids (As, $\mathrm{Cr}, \mathrm{Ni}, \mathrm{Cu}, \mathrm{Zn}, \mathrm{Cd}$, and $\mathrm{Pb}$ ) were analyzed using inductively coupled plasma-atomic emission spectroscopy (ICP-AES). Significant accumulation of $\mathrm{As}, \mathrm{Cd}$, and $\mathrm{Cr}$ was found in soils of
\end{abstract}

W. Luo · Y. Lu (ه) · T. Wang · Y. Shi ·

G. Wang - Y. Xing

Research Center for Eco-Environmental Sciences, Chinese Academy of Sciences, P.O. Box 2871, Beijing 100085, P.R. China

e-mail: yllu@rcees.ac.cn

J. P. Giesy

Department of Veterinary Biomedical Sciences \&

Toxicology Center, University of Saskatchewan,

Saskatoon, Canada

J. P. Giesy

Department of Zoology, National Food Safety and Toxicology Center and Center for Integrative Toxicology, Michigan State University, East Lansing, MI 48824, USA

J. P. Giesy

Department of Biology and Chemistry, City University of Hong Kong, Kowloon, Hong Kong, SAR China arable land. Based on correlation and cluster analysis, it can be concluded that $\mathrm{Cd}$ and $\mathrm{Zn}$ originate mainly from phosphate fertilizer, $\mathrm{Pb}$ from the use of insecticides, fertilizers, and sewage sludge as well as air deposition, and $\mathrm{Cu}$ from copper-based fungicides, while As, $\mathrm{Ni}$ and $\mathrm{Cr}$ might come from parent soil material. According to an ecological risk analysis of metals based on the ecological index suggested by Hakanson, the four types of land can be ranked by severity of ecological risk as follows: arable land $>$ woodland $>$ bare land $>$ orchard land, with a high ecological risk of $\mathrm{Cd}$ for all four types. Management measures for land use planners for avoiding water, soil, and sediment pollution caused by metals around the Guanting Reservoir are presented.

Keywords Metals - Land use - Ecological risk

\section{Introduction}

Soils are of central significance in ecosystem research because they are the site of many kinds of interactions between minerals, air, water, and the living environment (Bloemena et al. 1995). Soil generally reacts more slowly to outside influences than do water and air, as it is able to bind substances or incorporate them into soil complexes. In this way, soil accumulates both organic and inorganic substances. However, a side effect of this function is that 
soil collects not only nutrients but also pollutants (Adriano 1992). Since surface layers of soil, where pollutants can accumulate and reach relatively high concentrations, are the main rooting zone for vegetation and also the area with the greatest exposure to animal and human life, they are the focus of our research.

It is now accepted that the historical routine use of agrochemicals (such as pesticides and fertilizers) may have resulted in undesirable concentrations of trace elements, such as arsenic, cadmium, copper, mercury, lead, and zinc accumulating in some soils (Van Gaans et al. 1995; Merwin et al. 1994; Webber and Wang 1995; Harris et al. 2000). The contamination of soil with elevated concentrations of trace elements can have adverse effects on soil biology (microbiological communities and invertebrates) and hence soil ecosystem function (Merrington et al. 2002; Giller et al. 1998). Elevated concentrations of trace elements in soils can also have phytotoxic effects and result in trace element contamination of edible crops (Merry et al. 1986; Cobb et al. 2000). Humans can be exposed to toxic trace elements through direct soil ingestion as well as through the consumption of food produced on contaminated land (Nicholson et al. 2003).

Land use change can simultaneously cause both beneficial and harmful effects, because any change in land use has important consequences for many biological, chemical, and physical processes in soils and so, indirectly, the environment (Goulding et al. 1995; Goulding and Blake 1998, 1993; Sverdrup et al. 1995). Soil pollution (especially metal pollution) has become an important environmental issue in developed countries (e.g., the Netherlands, the United Kingdom, and Spain) due to changes in the land use pattern over the last few decades (Adriano 2001). Knowledge of metal concentrations for different land use types, which has scarcely been investigated, is of critical importance in assessing human impact on metal concentrations in soils (Chen et al. 2005a). There have been several studies on the accumulation of metals in soils under different land use in China, with different accumulation effects being found in soils under different land use (Zheng et al. 2005a, b, c, d; Chen et al. 2005b, c; Bloemena et al. 1995; Gaw et al. 2006). However, past studies focused mainly on the metal contaminations of soils affected by farming, industry, or urban development. There have been few studies on the metal contamination of soils in ecologically sensitive areas such reservoir areas, which are the source sites of drinking water.

The Guanting Reservoir is one of the five major water systems in Beijing. Prior to 1997, water from the reservoir was used as a source of drinking water for Beijing. Since then, however, industrial pollution and farming contamination have substantially degraded the quality of water in the reservoir (Ma et al. 2001; Wang et al. 2003). Soil can be polluted by wastewater irrigation. The metals in soils can also reach aquatic ecosystems by erosion and runoff from agricultural land (Pinay et al. 1992). Soils contaminated in these ways may have an impact on water quality. Protection of the soil around the Guanting Reservoir is of great importance for safeguarding the water quality in the reservoir.

Currently there is limited information available to regulatory authorities with a mandate to manage metals in soils under different land uses around the Guanting Reservoir. Analysis of the effects of land use on metal concentrations in soils is, therefore, critical for the making of policies aimed at reducing metal inputs to soil and guaranteeing the maintenance or even improvement of soil functions and water quality of the reservoir. The data provided in this study are considered important for reservoir remediation, especially since the Guanting Reservoir will serve as one of the main drinking water sources for Beijing in the foreseeable future. In this work, the potential ecological risk of soil contamination was assessed using the contamination factors and degrees of contamination suggested by Hakanson (1980). The ecological risk index was used as a diagnostic tool for determining the degree of pollution in sediment or soil.

The aims of the study were (1) to determine contents of $\mathrm{As}, \mathrm{Cd}, \mathrm{Cr}, \mathrm{Cu}, \mathrm{Ni}, \mathrm{Pb}$ and $\mathrm{Zn}$ in soils of different land use; (2) to determine their natural or anthropogenic source using multivariate analysis; and (3) to assess the ecological risk from different land uses and provide land planners with some management policies to reduce the input of metals into the environment.

\section{Materials and methods}

Site description

The Guanting Reservoir is located northwest of Beijing city (Latitude $40.19^{\circ} \sim 40.50^{\circ}$, Longitude 
$\left.115.43^{\circ} \sim 115.97^{\circ}\right)$. The study area covers about $920 \mathrm{~km}^{2}$, including the $98 \mathrm{~km}^{2}$ reservoir and $820 \mathrm{~km}^{2}$ of surrounding land. The land use types around the Guanting Reservoir are woodland, orchard land, arable land, and bare land, which together account for about $90 \%$ of the total area. Agriculture is the major land-use in the area around the Guanting Reservoir. From the 1960s to the 1980s, large amounts of agrochemicals were applied to the agricultural areas of the Guanting Reservoir. In the past several years, the average chemical fertilizer application was about $107 \mathrm{~kg} / \mathrm{ha}$ and pesticide usage was about $4.5 \mathrm{~kg} / \mathrm{ha}$. However, the efficiency of their usage was only 30-60\%. Most chemical fertilizers and pesticides used entered the water environment by several means such as surface water run-off and soil erosion. The major soil type in this area is calcareous cinnamon soil. The main parent materials are lithogenic rocks. The characteristics of soils are as follows: $\mathrm{pH}=7.6 \pm 0.2$, total $\mathrm{P}=666 \pm 37 \mathrm{mg} / \mathrm{kg}$, total $\mathrm{N}=1203 \pm 174 \mathrm{mg} / \mathrm{kg}$, total $\mathrm{C}=1.8 \pm 1.3 \%$.

\section{Sampling}

Sampling sites around Guanting Reservoir (Fig. 1) were selected according to land use. Results are reported for 52 composite soil samples. At each sampling site, five surface samples $(0-10 \mathrm{~cm}$ in depth) were collected from a $100 \times 100 \mathrm{~m}^{2}$ plot

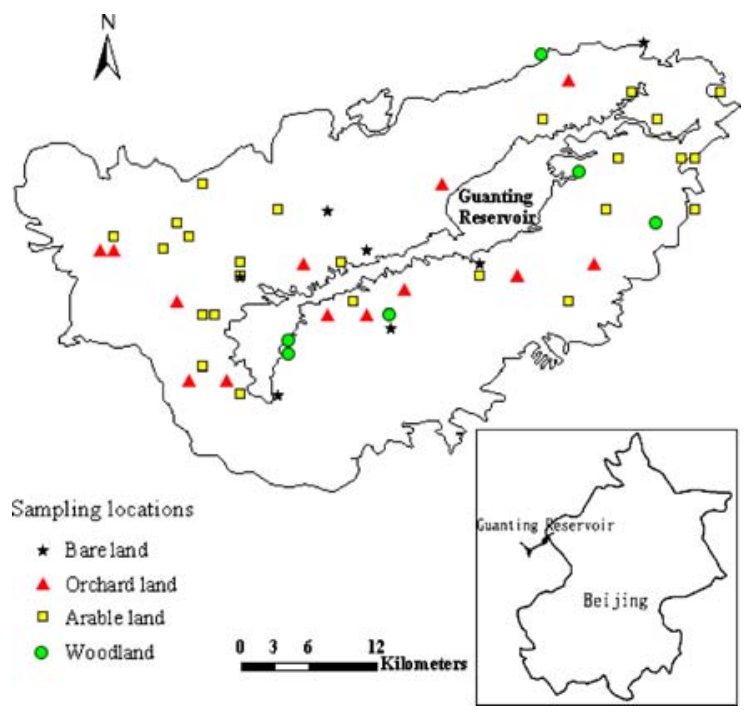

Fig. 1 Sampling locations around the Guanting Reservoir (located on crossing diagonals: four in the corners and one at the crossing point). A composite surface soil sample was collected from each sampling plot. The sampling scheme takes into account sites representing the most relevant characteristics of the environment and each soil type.

Metal analysis

Soil samples were air-dried, crushed in an agate mortar, passed through a nylon sieve of $0.149 \mathrm{~mm}$, and digested with $\mathrm{HNO}_{3}$ and $\mathrm{H}_{2} \mathrm{O}_{2}$ using Method 3050B (USEPA 1996). Concentrations of metals (Cd, $\mathrm{As}, \mathrm{Cu}, \mathrm{Ni}, \mathrm{Pb}$ and $\mathrm{Zn}$ ) in the digestion solution were determined using inductively coupled plasma-atomic emission spectroscopy (ICP-AES). The method detection limit (MDL), which is defined as the minimum concentration of substance that can be measured and reported with $99 \%$ confidence, was determined using EPA 40CFR Part 136, Appendix B. Standard reference materials, GSS-1 soils obtained from the Center of National Standard Reference Material of China, were analyzed as part of the quality assurance and quality control (QA/QC) procedures. Rigorous QA/QC protocols were followed, including insertion of "blind" standard reference materials for determination of the accuracy of the methods, and analytical duplicates to allow estimation of the precision of the method. Satisfactory recoveries were obtained for $\mathrm{Cu}(92-$ 95\%), Ni (101-108\%), Pb (94-106\%), Cd (96-99\%), As (97-101\%) and $\mathrm{Zn}(94-103 \%)$.

\section{Statistical analyses}

Statistical analyses were conducted using Microsoft Excel and SPSS 10.01 software (SPSS, Chicago, IL). The distribution of data was tested with the Kolmogorov-Smirnov method. Statistical evaluation was performed by analysis of variance (ANOVA), and Pearson's rank correlation (data with normal distribution). Post-hoc tests were employed with LSD (the data were normally distributed and passed the test of homogeneity of variances). The level of significance was set at $P<0.05$ (two-tailed).

To evaluate the analytical data, correlation analysis and cluster analysis (CA) were used. The Pearson correlation coefficient (data with normal 
distribution), $r$, was used to measure the strength of a linear relationship between two metals. CA was used to elucidate the latent relationships between heavy metals in soils of the same kind of land use around the Guanting Reservoir, and for investigating heavy metal sources. Hierarchical CA was performed using the following settings: the linkage type used was furthest neighbor and the distance method was the Pearson correlation.

\section{Results and discussion}

Descriptive parameters and probability distribution of the concentrations of metals around the Guanting Reservoir

Since the probability distributions of the raw data sets of $\mathrm{Cu}$ and $\mathrm{Pb}$ were heavily skewed, it was necessary to transform data prior to further statistical analyses. Descriptive parameters and probability distributed are shown in Table 1 . The Kolmogorov-Smirnov test indicated that the concentrations of $\mathrm{As}, \mathrm{Cd}, \mathrm{Cr}, \mathrm{Ni}$ and $\mathrm{Zn}$ followed normal distributions and that those of $\mathrm{Cu}$ and $\mathrm{Pb}$ were ln-normal distributed (K-S $P>0.05$ ). Combining all data yielded a normal distribution and allowed a confident comparison of mean values for different types of land use.

The range of $\mathrm{Pb}(164.88 \mathrm{mg} / \mathrm{kg}$ dry wt) (between the minimum and maximum values) was largest, and its variation (coefficient of variation $=274.04 \%$ ) and skewness $($ skew $=6.89$ ) were also the highest of all the studied samples. This suggests that there are several locations having great $\mathrm{Pb}$ concentrations, which means the soil in some areas is more contaminated.

The coefficients of variation for most metals, except $\mathrm{Cu}$ and $\mathrm{Pb}$, were between 20 and 40\%. This means that human activities have moderate effects on the concentrations of most metal pollution in soils around the Guanting Reservoir.

Based on the range of background concentration shown in Table 1 , most of the As, $\mathrm{Cr}$, and $\mathrm{Ni}$ values measured in soils are within their corresponding range of background concentrations. However, some values of $\mathrm{Cd}, \mathrm{Pb}, \mathrm{Cu}$, and $\mathrm{Zn}$ exceed the range of the corresponding background concentrations. This result suggests that, in some locations, pollution $\mathrm{Cd}, \mathrm{Pb}, \mathrm{Cu}$, and $\mathrm{Zn}$ in soils has taken place. The concentrations of $\mathrm{Cu}$ and $\mathrm{Pb}$ in some locations have values in the range considered toxic to plants (Table 1). Although the $\mathrm{Cd}$ concentrations in all samples exceeded the mean background concentration, they do not exceed the range considered toxic for plant growth $(3-8 \mathrm{mg} / \mathrm{kg}$ dry wt).

Effects of land use on concentrations of metals in top soils around the Guanting Reservoir

Four types of land uses (arable land, orchard land, bare land, and woodland) were identified for the Guanting Reservoir area. Concentrations of metals in soils from different land uses are presented in Table 2. Based on the results of an ANOVA of metal concentrations in soils of different land use (Table 3), there were significant differences between different land uses for $\mathrm{As}, \mathrm{Cd}$ and $\mathrm{Cr}$, and no significant differences for $\mathrm{Cu}, \mathrm{Ni}, \mathrm{Pb}$ and $\mathrm{Zn}$. Using post-hoc tests with LSD, it was found that significantly greater concentrations of $\mathrm{As}, \mathrm{Cd}$, and $\mathrm{Cr}$ values existed in soils of arable land around the Guanting Reservoir. However, mean concentrations of $\mathrm{Cu}$ and $\mathrm{Pb}$ that occurred in soils of orchard land were not significantly greater than those in other types of land (Table 2).

Correlation analysis was conducted to determine the extent of the relationships among metals in soils of different land use. The correlation matrix in Table 4 shows that $\mathrm{Pb}$ does not correlate with any metal in soils of arable land $(P>0.05)$, suggesting perhaps different soil sources from other metals. Cd, $\mathrm{Cr}, \mathrm{Ni}$, and $\mathrm{Zn}$ are closely related to each other $(r>0.92, P<0.01)$. This suggests that $\mathrm{Cd}, \mathrm{Cr}, \mathrm{Ni}$, and $\mathrm{Zn}$ may have another common origin.

In soils of orchard land, $\mathrm{Ni}, \mathrm{As}, \mathrm{Cd}$, and $\mathrm{Cr}$ are closely related to each other $(r>0.8, P<0.01)$ (Table 4), suggesting they have a common source. $\mathrm{Pb}$ and $\mathrm{Zn}$ form another group based on their significantly positive correlation $(r=0.81, P<0.01)$. This suggests that $\mathrm{Pb}$ and $\mathrm{Zn}$ might have another source. $\mathrm{Cu}$ is poorly correlated with other metals, which means that it has a source different from the two sources above.

The correlation matrix in Table 5 shows that $\mathrm{Pb}$ is weakly correlated with other metals (except $\mathrm{Ni}$ ) in soils of bare land $(P>0.05)$, while concentrations of As, 
Table 1 Summary statistics of heavy metals in soils around the Guanting Reservoir (mg/kg dry wt)

\begin{tabular}{|c|c|c|c|c|c|c|c|}
\hline & As & $\mathrm{Cd}$ & $\mathrm{Cr}$ & $\mathrm{Cu}$ & $\mathrm{Ni}$ & $\mathrm{Pb}$ & $\mathrm{Zn}$ \\
\hline Minimum & 3.06 & 0.39 & 16.78 & 2.86 & 5.95 & 1.74 & 22.99 \\
\hline Maximum & 10.9 & 1.2 & 59.36 & 64.37 & 33.33 & 164.88 & 109.33 \\
\hline Mean & 6.88 & 0.68 & 32.35 & 13.54 & 15.81 & 8.21 & 54.28 \\
\hline Skew & -0.03 & 0.8 & 0.97 & 2.93 & 1.04 & 6.89 & 0.96 \\
\hline Kurt. & -0.83 & 1.23 & 1.52 & 12.63 & 1.17 & 48.63 & 1.36 \\
\hline Coefficient of variation, $\%$ & 30.66 & 24.67 & 26.73 & 73.44 & 38.17 & 274.04 & 32.36 \\
\hline $\mathrm{K}-\mathrm{S} P$ & 0.89 & 0.34 & 0.43 & $0.91^{\mathrm{a}}$ & 0.24 & $0.12^{\mathrm{a}}$ & 0.29 \\
\hline Mean of background concentration ${ }^{\mathrm{b}}$ & $7.81 \pm 3.22$ & $0.15 \pm 0.11$ & $31.3 \pm 9.29$ & $19.7 \pm 6.33$ & $27.9 \pm 7.90$ & $25.1 \pm 5.08$ & $59.6 \pm 16.29$ \\
\hline $\begin{array}{l}\text { Value considered toxic range } \\
\text { for plant growth }\end{array}$ & 20 & $3-8$ & $75-100$ & $60-125$ & 100 & $100-400$ & $70-400$ \\
\hline \multicolumn{8}{|l|}{${ }^{a}$ Data set is $\ln$-transformed } \\
\hline \multicolumn{8}{|l|}{${ }^{\mathrm{b}}$ Chen et al. (2004) } \\
\hline \multicolumn{8}{|l|}{ c Ross (1994) } \\
\hline d Singh and Steinnes (1994) & & & & & & & \\
\hline
\end{tabular}

$\mathrm{Cd}, \mathrm{Cr}, \mathrm{Cu}, \mathrm{Ni}$, and $\mathrm{Zn}$ were correlated $(P<0.05)$. However, there were correlations between concentrations of $\mathrm{As}$ and $\mathrm{Cu}, \mathrm{Cr}$ and $\mathrm{Cu}$, and $\mathrm{Ni}$, between $\mathrm{Pb}$ and $\mathrm{Zn}$ in soils of woodland $(P<0.05)$, while $\mathrm{Cd}$ was significantly related to $\mathrm{Zn}(P<0.01)$.

The correlation analysis provides little information about the sources of metals. Thus, cluster analysis was performed on elemental concentrations in the arable land, orchard land, bare land, and woodland soils, using the furthest neighbor linkage method based on correlation coefficients (the Pearson coefficient). The results are illustrated in the dendrograms in Figs. 2-4. The distance cluster represents the degree of association between elements. The smaller the value on the distance cluster, the more significant the association. A criterion for distance clusters requiring that they be between 10 and 15 was adopted.

In arable soils, three distinct clusters were identified (Fig. 2). Cluster I contains $\mathrm{Cr}, \mathrm{Ni}, \mathrm{Cd}, \mathrm{Zn}, \mathrm{As}$, and $\mathrm{Cu}$. Since the concentrations of $\mathrm{Cr}$ and $\mathrm{Ni}$ in soils of arable land are less than their corresponding background concentrations, it can be deduced that they originated from natural sources. However, the mean concentration of $\mathrm{Cd}$ is greatest in soils of all kinds of land use. This might be caused to a great extent by the large-scale land application of phosphate fertilizers that contained $\mathrm{Zn}$, As, and $\mathrm{Cr}$ (Yang et al. 2004; Ma and Liu 1998; Wang 2000; Tayler 1997). In addition, wastewater irrigation and land application of sludge are likely important sources of $\mathrm{Cd}$ and $\mathrm{Cr}$ in soils around Guanting Reservoir (Sun and Hao 2004). In addition, the elevated concentrations of arsenic on arable land have resulted from the use of arsenic-based insecticides to control chewing insects (Merry et al. 1983; NSWEPA 1995). In summary, these metals probably came from natural parent materials of soils, application of pesticide and fertilizer, and wastewater irrigation.

Cluster II contains $\mathrm{Pb}$, which have originated from the natural parent materials of the soils because the range of $\mathrm{Pb}$ on arable land is $1.95-11.17 \mathrm{mg} / \mathrm{kg}$ dry wt (Table 2), which is less than the limited range of its background concentration $(11.5-38.2 \mathrm{mg} / \mathrm{kg}$ dry wt, shown in Table 1).

In orchard soils, three distinct clusters can be identified (Fig. 3). Cluster I contains $\mathrm{Cr}, \mathrm{Ni}, \mathrm{As}$, and $\mathrm{Cd}$. Although there is no significant difference for each of these metals in soils among orchard land, bare land, and woodland (Table 2), it should be emphasized that the concentrations of these metals in orchard land still represent a considerable absolute quantity. It can be deduced that $\mathrm{Cr}, \mathrm{Ni}, \mathrm{As}$, and $\mathrm{Cd}$ probably came from natural materials.

Cluster II contains $\mathrm{Cu}$. The mean concentration of $\mathrm{Cu}$ on orchard land around Guanting Reservoir represents a considerable absolute quantity greater than those in the other types of land. There is a long history of grape cultivation (more than 1,200 years) around Guanting Reservoir. More than ten large 
Table 2 The concentrations of heavy metals in soils from different land use around the Guanting Reservoir (mg/kg dry wt)

\begin{tabular}{|c|c|c|c|c|c|}
\hline Heavy metal & Land use & Mean* & SD & Minimum & Maximum \\
\hline \multirow[t]{4}{*}{ As } & Arable land $(n=25)$ & $7.80^{\mathrm{a}}$ & 2.00 & 3.31 & 10.90 \\
\hline & Orchard land $(n=14)$ & $5.57^{\mathrm{b}}$ & 2.02 & 3.06 & 8.79 \\
\hline & Bare land $(n=7)$ & $6.70^{\mathrm{ab}}$ & 1.72 & 3.68 & 8.65 \\
\hline & Woodland $(n=6)$ & $6.30^{\mathrm{ab}}$ & 1.56 & 4.58 & 8.44 \\
\hline \multirow[t]{4}{*}{$\mathrm{Cd}$} & Arable land $(n=25)$ & $0.75^{\mathrm{a}}$ & 0.17 & 0.53 & 1.20 \\
\hline & Orchard land $(n=14)$ & $0.60^{\mathrm{b}}$ & 0.14 & 0.39 & 0.79 \\
\hline & Bare land $(n=7)$ & $0.63^{\mathrm{ab}}$ & 0.13 & 0.39 & 0.75 \\
\hline & Woodland $(n=6)$ & $0.66^{\mathrm{ab}}$ & 0.16 & 0.50 & 0.92 \\
\hline \multirow[t]{4}{*}{$\mathrm{Cr}$} & Arable land $(n=25)$ & $35.98^{\mathrm{a}}$ & 9.62 & 20.76 & 59.36 \\
\hline & Orchard land $(n=14)$ & $27.87^{\mathrm{b}}$ & 6.05 & 20.05 & 38.57 \\
\hline & Bare land & $30.41^{\mathrm{ab}}$ & 6.99 & 16.78 & 38.00 \\
\hline & Woodland $(n=6)$ & $29.96^{\mathrm{ab}}$ & 5.52 & 25.70 & 38.13 \\
\hline \multirow[t]{4}{*}{$\mathrm{Cu}$} & Arable land $(n=25)$ & $14.68^{\mathrm{a}}$ & 6.94 & 4.99 & 28.61 \\
\hline & Orchard land $(n=14)$ & $15.81^{\mathrm{a}}$ & 16.07 & 3.94 & 64.37 \\
\hline & Bare land $(n=7)$ & $9.50^{\mathrm{a}}$ & 3.70 & 3.07 & 13.53 \\
\hline & Woodland $(n=6)$ & $8.24^{\mathrm{a}}$ & 3.61 & 2.86 & 12.76 \\
\hline \multirow[t]{4}{*}{$\mathrm{Ni}$} & Arable land $(n=25)$ & $17.76^{\mathrm{a}}$ & 6.51 & 8.08 & 33.33 \\
\hline & Orchard land $(n=14)$ & $13.72^{\mathrm{a}}$ & 5.93 & 5.95 & 30.04 \\
\hline & Bare land $(n=7)$ & $14.70^{\mathrm{a}}$ & 4.25 & 6.25 & 18.39 \\
\hline & Woodland $(n=6)$ & $13.87 \mathrm{a}$ & 4.21 & 10.22 & 21.63 \\
\hline \multirow[t]{4}{*}{$\mathrm{Pb}$} & Arable land $(n=25)$ & $5.31^{\mathrm{a}}$ & 2.09 & 1.95 & 11.17 \\
\hline & Orchard land $(n=14)$ & $17.16^{\mathrm{a}}$ & 43.10 & 1.77 & 164.88 \\
\hline & Bare land $(n=7)$ & $3.86^{\mathrm{a}}$ & 1.11 & 2.00 & 5.80 \\
\hline & Woodland $(n=6)$ & $4.51^{\mathrm{a}}$ & 2.00 & 1.74 & 7.82 \\
\hline \multirow[t]{4}{*}{$\mathrm{Zn}$} & Arable land $(n=25)$ & $58.84^{\mathrm{a}}$ & 14.56 & 37.82 & 92.70 \\
\hline & Orchard land $(n=14)$ & $50.11^{\mathrm{a}}$ & 21.66 & 24.93 & 109.33 \\
\hline & Bare land $(n=7)$ & $46.08^{\mathrm{a}}$ & 12.43 & 22.99 & 58.05 \\
\hline & Woodland $(n=6)$ & $54.53^{\mathrm{a}}$ & 21.82 & 34.90 & 95.99 \\
\hline
\end{tabular}

Land uses followed by different letters are significantly different at the $P<0.05$ level

Table 3 ANOVA of heavy metals for different land uses around the Guanting Reservoir

\begin{tabular}{lllllllr}
\hline & As & $\mathrm{Cd}$ & $\mathrm{Cr}$ & $\mathrm{Ni}$ & $\mathrm{Zn}$ & $\mathrm{Cu}^{\mathrm{a}}$ & $\mathrm{Pb}^{\mathrm{a}}$ \\
\hline F & 4.227 & 3.125 & 3.417 & 1.797 & 1.362 & 2.008 & 0.427 \\
Significance & 0.010 & 0.034 & 0.025 & 0.160 & 0.265 & 0.125 & 0.734 \\
\hline
\end{tabular}

a $\ln$ transformation

grape vine plantations (including the famous Great Wall Grape Vine Plantation) are located in the area. A wide range of relatively high copper concentrations in orchard soils, especially in vineyard soils, has been reported in the international literature (Merry et al. 1983; Deluisa et al. 1996; Besnard et al. 2001). Holland and Solomona (1999) proposed that elevated soil copper concentrations in orchard soils arise from the long-term use of copper-based fungicides. The application of $\mathrm{Cu}$-based fungicide in former vineyards or orchards could be mainly responsible for the great concentration of $\mathrm{Cu}$ in orchard land around the Guanting Reservoir. Therefore, $\mathrm{Cu}$ in the orchards came from pesticides. 
Table 4 Correlations between heavy metal contents in the studied soils of arable land and orchard land ${ }^{\mathrm{a}}$

\begin{tabular}{|c|c|c|c|c|c|c|c|}
\hline & As & $\mathrm{Cd}$ & $\mathrm{Cr}$ & $\mathrm{Cu}$ & $\mathrm{Ni}$ & $\mathrm{Pb}$ & $\mathrm{Zn}$ \\
\hline As & & $0.69^{* *}$ & $0.72^{* *}$ & $0.63^{* *}$ & $0.64^{\text {** }}$ & 0.21 & $0.75^{\text {** }}$ \\
\hline $\mathrm{Cd}$ & $0.80^{* *}$ & & $0.96^{* *}$ & $0.78^{* *}$ & $0.94^{* *}$ & 0.21 & $0.94^{* *}$ \\
\hline $\mathrm{Cr}$ & $0.82^{* *}$ & $0.78^{* *}$ & & $0.79^{* *}$ & $0.97^{* *}$ & 0.18 & $0.92^{* * *}$ \\
\hline $\mathrm{Cu}$ & 0.39 & 0.31 & $0.60^{*}$ & & $0.80^{* *}$ & 0.10 & $0.85^{* *}$ \\
\hline $\mathrm{Ni}$ & $0.81^{* *}$ & $0.7^{* *}$ & $0.85^{* *}$ & 0.30 & & 0.20 & $0.92^{\text {** }}$ \\
\hline $\mathrm{Pb}$ & 0.00 & 0.41 & 0.08 & -0.04 & 0.01 & & 0.32 \\
\hline $\mathrm{Zn}$ & 0.48 & $0.78^{* *}$ & $0.54^{*}$ & 0.33 & 0.43 & $0.81^{* *}$ & \\
\hline
\end{tabular}

a Pearson coefficients for arable land and orchard land are shown above and below the diagonal line, respectively

* Correlation is significant at the 0.05 level (2-tailed)

** Correlation is significant at the 0.01 level (2-tailed)

Table 5 Correlations between heavy metal contents in the soils of bare land and woodland ${ }^{\mathrm{a}}$

\begin{tabular}{llllllll}
\hline & $\mathrm{As}$ & $\mathrm{Cd}$ & $\mathrm{Cr}$ & $\mathrm{Cu}$ & $\mathrm{Ni}$ & $\mathrm{Pb}$ & $\mathrm{Zn}$ \\
\hline $\mathrm{As}$ & & $0.86^{*}$ & $0.86^{*}$ & $0.89^{* *}$ & $0.92^{* *}$ & 0.75 & $0.86^{*}$ \\
$\mathrm{Cd}$ & -0.09 & & $0.96^{* *}$ & $0.96^{* *}$ & $0.94^{* *}$ & 0.75 & $0.99^{* *}$ \\
$\mathrm{Cr}$ & 0.76 & 0.22 & & $0.89^{* *}$ & $0.88^{* *}$ & 0.67 & $0.94^{* *}$ \\
$\mathrm{Cu}$ & $0.90^{*}$ & -0.25 & $0.82^{*}$ & & $0.96^{* *}$ & 0.75 & $0.98^{* *}$ \\
$\mathrm{Ni}$ & 0.74 & 0.17 & $0.87^{*}$ & $0.87^{*}$ & & $0.80^{*}$ & $0.95^{* *}$ \\
$\mathrm{~Pb}$ & -0.09 & $0.84^{*}$ & 0.04 & -0.41 & -0.15 & $0.77^{*}$ \\
$\mathrm{Zn}$ & -0.30 & $0.96^{* *}$ & 0.03 & -0.48 & -0.10 & $0.89^{*}$ \\
\hline
\end{tabular}

a Pearson coefficients for bare land and woodland are shown above and below the diagonal line, respectively

* Correlation is significant at the 0.05 level (2-tailed)

** Correlation is significant at the 0.01 level (2-tailed)

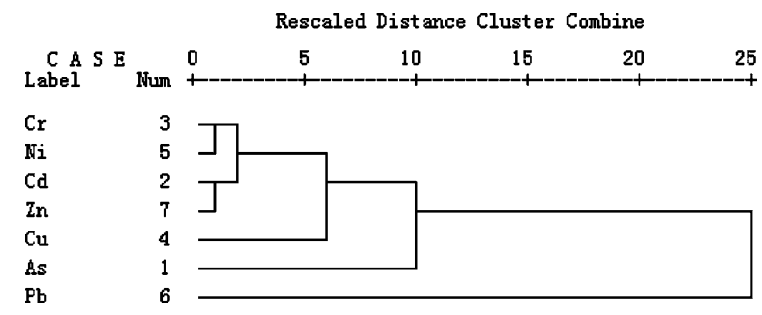

Fig. 2 Dendrogram of the cluster analysis of arable soils based on heavy metal concentrations

Cluster III contains $\mathrm{Pb}$ and $\mathrm{Zn}$. In our study, the mean concentration of $\mathrm{Pb}$ in orchard land was significantly great, which is consistent with other studies (Merry et al. 1983; Merwin et al. 1994; Gaw et al. 2003). The elevated lead concentrations in orchard samples has been shown to be most likely due to the use of insecticides that contained lead (Gaw et al. 2003). Zinc is an ingredient in

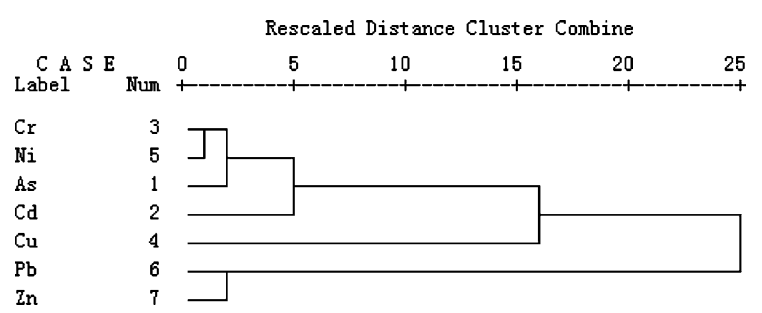

Fig. 3 Dendrogram of the cluster analysis of orchard soils based on heavy metal concentrations

pesticides, especially fungicides (Long 1983), and fertilizer use has been implicated in elevated zinc concentrations in soils (Taylor and Percival 2001). It was revealed by another study that the $\mathrm{Zn}$ content in soils came from long-term anthropogenic activity connected with grape-growing (Facchinelli et al. 2001). Thus, it can be concluded that $\mathrm{Zn}$ in soils of orchard land comes mainly from impurities 


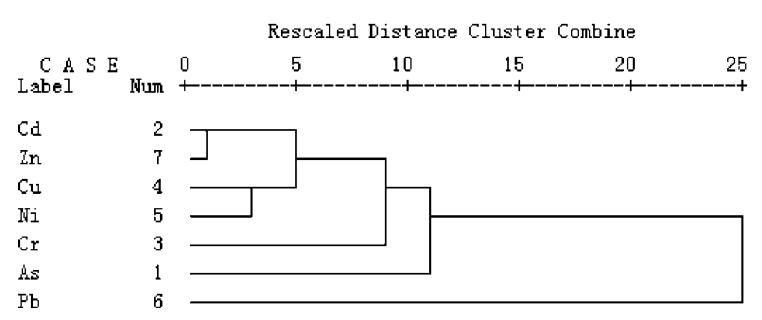

Fig. 4 Dendrogram of the cluster analysis of bare land soils based on heavy metal concentrations

in fertilizer and pesticides used in vineyards around Guanting Reservoir.

In the bare land soils, two distinct clusters were identified (Fig. 4). Cluster I contains As, Cd, Cr, $\mathrm{Zn}, \mathrm{Ni}$, and $\mathrm{Cu}$. Mean concentrations of $\mathrm{As}, \mathrm{Cr}$, and $\mathrm{Ni}$ in soils of bare land were greater than those in orchard and woodlands. It was estimated that about $1.6361 \times 10^{8}$ tons of industrial waste and domestic rubbish per year were dumped on bare land upstream of Guanting Reservoir (OLGGWP 1977; Du et al. 2004). (For example, concentrations of $\mathrm{Cd}$ in some sludge, pyrite, and phosphate rocks were $6.5,1.9$, and $0.2 \mathrm{mg} / \mathrm{kg}$ around Guanting Reservoir, respectively.) Thus, this cluster of metals might originate from land application of fertilizers and solid wastes.

Cluster II contains $\mathrm{Pb}$. The group of $\mathrm{Pb}$ is remarkably different from the other metals in terms of distance in CA, which implies a different origin from the other metals. The range of $\mathrm{Pb}$ in soils of bare land (Table 2) is less than the range of background concentrations of $\mathrm{Pb}$ (Table 1). It can be deduced that $\mathrm{Pb}$ came from natural parent materials of soils.

In woodland soils, two distinct clusters can be identified (Fig. 5). Cluster I contains $\mathrm{Cd}, \mathrm{Zn}$, and $\mathrm{Pb}$. Atmospheric pollutants might have affected forests and soils. In particular, the long-range atmospheric transport of metals could lead to pollutant deposition even in more remote areas (De Vries et al. 2002). In Sweden, for example, with increasing industrial activity, $\mathrm{Pb}$ and $\mathrm{Cd}$ contents have increased by $50 \%$ in upper soil organic layers (EEA 1998). An investigation showed that the Guanting Reservoir area was rich in coal mines, pyrite, and phosphate rocks, which contain large concentrations of $\mathrm{Cd}$ and $\mathrm{Zn}$ (OLGGWP 1977). This means that air deposition may be responsible for the high concentrations of $\mathrm{Cd}, \mathrm{Zn}$, and $\mathrm{Pb}$ in some woodland soils.
Cluster II contains $\mathrm{Cr}, \mathrm{Ni}, \mathrm{Cu}$, and As. Concentrations of these metals in woodland are significantly less than those in arable land (Table 2). Woodland soil contained less $\mathrm{Cr}, \mathrm{Ni}, \mathrm{Cu}$, and As because it had received less fertilizer and pesticide than arable and orchard soils. This means that these metals may originate from the natural parent materials of the soils.

Assessment of ecological risks of metals in soils of different land use around the Guanting Reservoir

The assessment of soil contamination was conducted using the contamination factor and degree. In the version suggested by Hakanson (1980), an assessment of soil contamination was conducted through reference of the concentrations in the surface layer of bottom sediments to pre-industrial concentrations:

$C_{r}^{i}=\frac{C_{i}}{C_{n}^{i}}$.

Here $C_{i}$ is mean concentration of an individual metal examined and $C_{n}^{i}$ is the pre-industrial concentration of the individual metal. In our work, we applied the background concentration of a metal in the soil of Beijing (Table 1) as the pre-industrial concentration of each individual metal. $C_{r}^{i}$ is the single-element index. The sum of contamination factors for all metals examined represents the contamination degree $\left(C_{d}\right)$ of the environment:

$C_{d}=\sum_{i=1}^{n} C_{r}^{i}$

$E_{r}^{i}$ is the potential ecological risk index of an individual metal. It can be calculated by

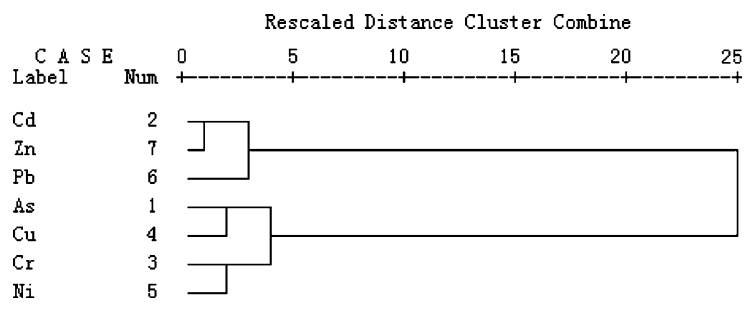

Fig. 5 Dendrogram of the cluster analysis of woodland soils based on heavy metal concentrations 
$E_{r}^{i}=T_{r}^{i} \times C_{r}^{i}$,

where $T_{r}^{i}$ is the toxic response factor provided by Hakanson $(\mathrm{Zn}=1, \mathrm{Cr}=2, \mathrm{Cu}=\mathrm{Ni}=\mathrm{Pb}=5, \mathrm{As}=$ $10, \mathrm{Cd}=30) . R I$ is the potential ecological risk index, which is the sum of $E_{r}^{i}$.

$R I=\sum_{i=1}^{n} E_{r}^{i}=\sum^{n} T_{r}^{i} \times C_{r}^{i}$

Hakanson (1980) defines four categories of $C_{r}^{i}$, four categories of $C_{d}$, five categories of $E_{r}^{i}$, and four categories of $R I$, as shown in Table 6 .

Based on the single-element index $\left(C_{r}^{i}\right)$ (Table 7) and its grades (Table 6), the soil of arable land was classified as moderately contaminated with As and $\mathrm{Cr}$, considerably contaminated with $\mathrm{Cd}$, and slightly contaminated with $\mathrm{Cu}, \mathrm{Ni}, \mathrm{Pb}$, and $\mathrm{Zn}$. The soils of orchard land, bare land, and woodland were classified as considerably contaminated with $\mathrm{Cd}$ and slightly contaminated with $\mathrm{As}, \mathrm{Cr}, \mathrm{Cu}, \mathrm{Ni}, \mathrm{Pb}$, and $\mathrm{Zn}$.

The assessment of the overall contamination of soil was based on the degree of contamination $\left(C_{d}\right)$. The degree of contamination was of the following order: arable land $>$ orchard land $>$ woodland $>$ bare land (Table 7). However, by ANOVA of $C_{d}$, it was found there was no significant difference $(P>0.05)$ for $C_{d}$ between land use. The range of $C_{d}$ for all kinds of land use is 7.99-9.75, which indicates moderate contamination of the environment around Guanting Reservoir. The maximum value of $C_{d}$ (16.33 in soils of orchard land, shown in Table 7) indicates considerable contamination in soils of orchard land.

Combining the potential ecological risk index of individual metals $\left(E_{r}^{i}\right)$ and the potential ecological risk index of the environment (RI) (Table 8) with their grade classifications (Table 6), soils in all kinds of land use were classified as posing considerable potential ecological risk with $\mathrm{Cd}$ and little potential ecological risk with $\mathrm{As}, \mathrm{Cr}, \mathrm{Cu}, \mathrm{Ni}, \mathrm{Pb}$, and $\mathrm{Zn}$. The potential ecological risk indices of the environment for the different types of land use can be ranked in the following order: arable land $>$ woodland $>$ bare land $>$ orchard land. Also, the potential ecological risk index of the environment of arable land was found to be significantly greater than that of orchard land by ANOVA of RI. However, further study is needed to

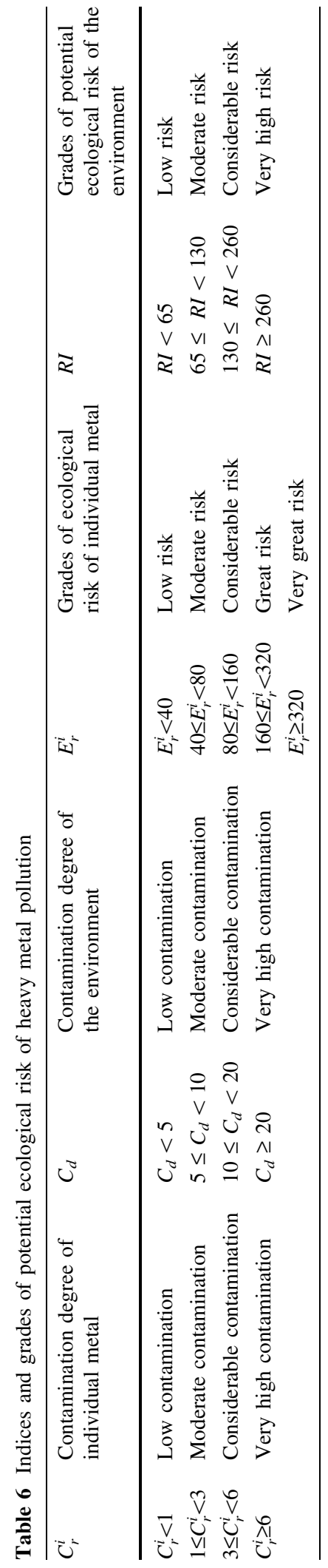


Table 7 Single-element index and degree of contamination in soils of different land use around the Guanting Reservoir

\begin{tabular}{|c|c|c|c|c|c|c|c|c|c|}
\hline & & \multicolumn{7}{|l|}{$C_{r}^{i}$} & \multirow[t]{2}{*}{$C_{d}$} \\
\hline & & As & $\mathrm{Cd}$ & $\mathrm{Cr}$ & $\mathrm{Cu}$ & $\mathrm{Ni}$ & $\mathrm{Pb}$ & $\mathrm{Zn}$ & \\
\hline \multirow[t]{4}{*}{ Arable land $(n=25)$} & Mean & 1.00 & 5.02 & 1.15 & 0.75 & 0.64 & 0.21 & 0.99 & 9.75 \\
\hline & SD & 0.26 & 1.16 & 0.31 & 0.35 & 0.23 & 0.08 & 0.24 & 2.42 \\
\hline & Min. & 0.42 & 3.53 & 0.66 & 0.25 & 0.29 & 0.08 & 0.63 & 6.21 \\
\hline & Max. & 1.40 & 8.00 & 1.90 & 1.45 & 1.19 & 0.45 & 1.56 & 15.5 \\
\hline \multirow[t]{4}{*}{ Orchard land $(n=13)$} & Mean & 0.71 & 4.00 & 0.89 & 0.80 & 0.49 & 0.68 & 0.84 & 8.43 \\
\hline & SD & 0.26 & 0.95 & 0.19 & 0.82 & 0.21 & 1.72 & 0.36 & 3.19 \\
\hline & Min. & 0.39 & 2.60 & 0.64 & 0.20 & 0.21 & 0.07 & 0.42 & 4.79 \\
\hline & Max. & 1.13 & 5.27 & 1.23 & 3.27 & 1.08 & 6.57 & 1.83 & 16.33 \\
\hline \multirow[t]{4}{*}{ Bare land $(n=7)$} & Mean & 0.86 & 4.22 & 0.97 & 0.48 & 0.53 & 0.15 & 0.77 & 7.99 \\
\hline & SD & 0.22 & 0.85 & 0.22 & 0.19 & 0.15 & 0.04 & 0.21 & 1.83 \\
\hline & Min. & 0.47 & 2.60 & 0.54 & 0.16 & 0.22 & 0.08 & 0.39 & 4.45 \\
\hline & Max. & 1.11 & 5.00 & 1.21 & 0.69 & 0.66 & 0.23 & 0.97 & 9.64 \\
\hline \multirow[t]{4}{*}{ Woodland $(n=6)$} & Mean & 0.81 & 4.37 & 0.96 & 0.42 & 0.50 & 0.18 & 0.92 & 8.14 \\
\hline & SD & 0.20 & 1.06 & 0.18 & 0.18 & 0.15 & 0.08 & 0.37 & 1.58 \\
\hline & Min. & 0.59 & 3.33 & 0.82 & 0.15 & 0.37 & 0.07 & 0.59 & 6.32 \\
\hline & Max. & 1.08 & 6.13 & 1.22 & 0.65 & 0.78 & 0.31 & 1.61 & 10.00 \\
\hline
\end{tabular}

Table 8 Potential ecological risk assessment results of heavy metals in soils of different land use

\begin{tabular}{|c|c|c|c|c|c|c|c|c|c|}
\hline & & \multicolumn{7}{|l|}{$E_{r}^{i}$} & \multirow[t]{2}{*}{$R I^{*}$} \\
\hline & & As & $\mathrm{Cd}$ & $\mathrm{Cr}$ & $\mathrm{Cu}$ & $\mathrm{Ni}$ & $\mathrm{Pb}$ & $\mathrm{Zn}$ & \\
\hline \multirow[t]{4}{*}{ Arable land $(n=25)$} & Mean & 9.99 & 150.48 & $2.30^{\mathrm{a}}$ & 3.73 & 3.18 & 1.06 & 0.99 & $171.72^{\mathrm{a}}$ \\
\hline & SD & 2.57 & 34.89 & 0.61 & 1.76 & 1.17 & 0.42 & 0.24 & 40.12 \\
\hline & Min. & 4.24 & 106.00 & 1.33 & 1.27 & 1.45 & 0.39 & 0.63 & 117.66 \\
\hline & Max. & 13.96 & 240.00 & 3.79 & 7.26 & 5.97 & 2.23 & 1.56 & 272.43 \\
\hline \multirow[t]{4}{*}{ Orchard land $(n=13)$} & Mean & 7.14 & 120.14 & $1.78^{\mathrm{b}}$ & 4.01 & 2.46 & 3.42 & 0.84 & $139.79^{b}$ \\
\hline & SD & 2.59 & 28.38 & 0.39 & 4.08 & 1.06 & 8.59 & 0.36 & 37.35 \\
\hline & Min. & 3.92 & 78.00 & 1.28 & 1.00 & 1.07 & 0.35 & 0.42 & 87.31 \\
\hline & Max. & 11.25 & 150.00 & 2.46 & 16.34 & 5.38 & 32.84 & 1.83 & 203.25 \\
\hline \multirow[t]{4}{*}{ Bare land $(n=7)$} & Mean & 8.58 & 126.57 & 1.94 & 2.41 & 2.63 & 0.77 & 0.77 & $143.69^{\mathrm{ab}}$ \\
\hline & SD & 2.20 & 25.53 & 0.45 & 0.94 & 0.76 & 0.22 & 0.21 & 29.87 \\
\hline & Min. & 4.71 & 78.00 & 1.07 & 0.78 & 1.12 & 0.40 & 0.39 & 86.47 \\
\hline & Max. & 11.08 & 150.00 & 2.43 & 3.43 & 3.30 & 1.16 & 0.97 & 170.59 \\
\hline \multirow[t]{4}{*}{ Woodland $(n=6)$} & Mean & 8.06 & 131.00 & 1.91 & 2.09 & 2.48 & 0.90 & 0.91 & $147.37^{\mathrm{ab}}$ \\
\hline & SD & 2.00 & 31.72 & 0.35 & 0.92 & 0.75 & 0.40 & 0.37 & 32.41 \\
\hline & Min. & 5.86 & 100.00 & 1.64 & 0.73 & 1.83 & 0.35 & 0.59 & 113.64 \\
\hline & Max. & 10.81 & 184.00 & 2.44 & 3.24 & 3.88 & 1.56 & 1.61 & 197.28 \\
\hline
\end{tabular}

* Land uses followed bydifferent letters are significantly different at the $P<0.05$ level

explain the reasons for the greater potential ecological risk caused mainly by $\mathrm{Cd}$ in woodland soils. On the whole, the range of $R I$ for all kinds of land use is
139.79-171.72, indicating considerable potential ecological risk around Guanting Reservoir. The maximum value of $R I$ (272.43 in soils of arable land, 
shown in Table 8) denotes very high potential ecological risk for arable land.

The results presented here also have implications for managing land. Of the contaminants detected in this work, the concentrations of $\mathrm{Cd}$ were most problematic in terms of their potential ecological risk. Although most metal concentrations in soils sampled around Guanting Reservoir did not exceed values considered toxic for plant growth (Table 1), concentrations of $\mathrm{Cu}$ and $\mathrm{Pb}$ in soils of orchard land are within the range of values considered toxic for plants (Tables 1, 2). Therefore, some remediation measures will be needed for soils of orchard land in terms of food safety. Moreover, the continued input of $\mathrm{Cd}, \mathrm{Cr}$, and As into arable land, and of $\mathrm{Cd}, \mathrm{Cr}, \mathrm{Cu}, \mathrm{As}$, and $\mathrm{Pb}$ into orchard land will also need to be managed in order to protect the soil resources. $\mathrm{Cd}$, As, and $\mathrm{Ni}$ have great mobility in soil and are likely to pollute the groundwater, and even underground water nearby (Li and Pu 1992; Conner 1994; Babich et al. 1998). To avoid water and sediment pollution caused by metals in soils around Guanting Reservoir, most farming activities along the Guanting Reservoir should be banned in future.

\section{Conclusion}

A significant degree of metal pollution, particularly $\mathrm{Cd}, \mathrm{Cr}$, and As. Cd and $\mathrm{Zn}$, exists in some soils of arable land around Guanting Reservoir. Such pollution probably originates mainly from phosphate fertilizer, $\mathrm{Pb}$ from the use of insecticides, fertilizers, and sludge as well as air deposition, and $\mathrm{Cu}$ from copper-based fungicides, while $\mathrm{As}, \mathrm{Ni}$, and $\mathrm{Cr}$ might come from soil parent material. Moderate contamination of the environment was found around the Guanting Reservoir with the following order of degree of contamination: arable land $>$ orchard land $>$ woodland $>$ bare land. However, the potential ecological risk index to the environment was of the following order: arable land $>$ woodland $>$ bare land $>$ orchard land, with considerable potential ecological risk from $\mathrm{Cd}$ for all kinds of land use. This means that the inputs of $\mathrm{Cd}, \mathrm{Cr}$, and As for arable land, and of $\mathrm{Cd}, \mathrm{Cr}, \mathrm{Cu}, \mathrm{As}$, and $\mathrm{Pb}$ for orchard land will need to be managed in order to protect the environment around the Guanting Reservoir. Some remediation measures will be needed for soils of orchard land in the interests of food safety.

Acknowledgments This research was supported by the National Basic Research Program (the "973" Research Program) with grantNo. 2007CB407307. The authors thank Dr. Xugang Luo, professor of animal nutrition in the China Agricultural Academy of Sciences, for analytical determinations of metal by ICAPES, and Dr. Tongbin Chen, Director of the Center of Environmental Remediation, Institute of Geographical Science and Resources Research, Chinese Academy of Sciences, for his assistance with lab facilities. The authors are particularly grateful to Dr. Guodi Zheng and Wei Gao for sample preparation. We also thank the reviewers for their comments on this paper.

\section{References}

Adriano, D. C. (Ed.) (1992). Biogeochemistry of trace metals. In S. J. Buckland, H. K. Ellis \& R. T. Salter (Eds), Ambient concentrations of selected organochlorines in soils. Organochlorines programme. Wellington, New Zealand: Ministry for the Environment 1998.96 pp. Boca Raton, Florida: Lewis

Adriano, D. C. (2001). Trace elements in terrestrial environments. biogeochemistry, bioavailability and risks of metals. New York: Springer.

Babich, S., Kastelan-Macan, M., \& Petrovic, M. (1998). Determination of agrochemicals combinations in spiked soil samples. Water Science and Technology, 7, 243-250.

Besnard, E., Chenu, C., \& Robert, M. (2001). Influence of organic amendments on copper distribution among particle-size and density fractions in Champagne vineyard soils. Environmental Pollution, 112, 329-337.

Bloemena, M., Markert, B., \& Lieth, H. (1995). The distribution of $\mathrm{Cd}, \mathrm{Cu}, \mathrm{Pb}$ and $\mathrm{Zn}$ in topsoils of Osnabriick in relation to land use. The Science of the Total Environment, $166,137-148$.

Chen, T. B., Zheng, Y. M., \& Chen, H., et al. (2004). Background concentrations of soil heavy metals in Beijing Chinese (in Chinese). Journal of Environmental Science, 24, 117-122.

Chen, T. B., Zheng, Y. M., \& Chen, H., et al. (2005a). Arsenic accumulation in soils for different land use types in Beijing (in Chinese). Geographical Research, 24, 229235.

Chen, T. B., Zheng, Y. M., \& Chen, H., et al. (2005b). Arsenic accumulation in soils for different land use types in Beijing (in Chinese). Geographical Research, 24, 229235.

Chen, T. B., Zheng, Y. M., \& Lei, M., et al. (2005c). Assessment of heavy metal pollution in surface soils of urban parks in Beijing, China. Chemosphere, 60, 542551.

Cobb, G. P., Sands, K., Waters, M., Wixson, B. G., \& DowardKing, E. (2000). Accumulation of heavy metals by vegetables grown in mine wastes. Environmental Toxicology and Chemistry, 19, 600-607. 
Conner, J. R. (1994). In J. David \& N. C. Ann (Eds.), Chemical stabilization of contaminated soils: hazardous waste site soil remediation theory and application of innovative technologies. Contaminated Soils (pp. 81-169). Boston: Lewis.

De Vries, W., Vel, E., Reinds, G. J., Deelstra, H., Klap, J. M., Leeters, E. E. J. M., Hendriks, C. M. A., Kerkvoorden, M., Landmann, G., Herkendell, J., Haussmann, T., \& Erisman, J. W. (2002). Intensive monitoring of forest ecosystems in Europe 1. Objectives, set-up and evaluation strategy. Forest Ecology and Management, 5890, 1-19.

Deluisa, A., Giandonm, P., Aichner, M., Bortolami, P., Bruna, L., \& Lupetti, A., et al. (1996). Copper pollution in Italian vineyard soils. Communications in Soil Science and Plant Analysis, 27, 1537-1548.

Du, G. S., Wang, J. T., Zhang, W. H., Feng, L. Q., \& Liu, J. (2004). On the nutrient status of Guanting Reservoir, 2001-2002 (in Chinese). Journal of Lake Sciences, 16, 277-281.

EEA (European Environment Agency). (1998). Europe's environment: The second assessment. Amsterdam: Elsevier Science, pp. 293.

Facchinelli, A., Sacchi, E., \& Mallen, L., (2001). Multivariate statistical and GIS-based approach to identify heavy metal sources in soils. Environmental Pollution, 114, 313-324.

Gaw, S. K., Palmera, G., Kim, N. D., \& Wilkins, A. (2003). Preliminary evidence that copper inhibits the degradation of DDT to DDE in pip and stonefruit orchard soils in the Auckland region, New Zealand. Environmental Pollution, 122, 1-5.

Gaw, S. K., Wilkinsa, A. L., Kimc, N. D., Palmera, G. T., \& Robinsond, P. (2006). Trace element and SDDT concentrations in horticultural soils from the Tasman, Waikato and Auckland regions of New Zealand. Science of the Total Environment, 355, 31- 47.

Giller, K. E., Witter, E., \& McGrath, S. P. (1998). Toxicity of heavy metals to microorganisms and microbial processes in agricultural soils: a review. Soil Biology \& Biochemistry, 30, 1389-1414.

Goulding, K. W. T., \& Blake, L. (1993). Testing the PROFILE model on long term data. In: M. Hornung \& R. A. Skeffington (Eds.), Critical loads: Concept and applications (pp. 31-33). London: ITE Symposium 28, HMSO.

Goulding, K. W. T., \& Blake, L. (1998). Land use, liming and the mobilization of potentially toxic metals. Agriculture, Ecosystems and Environment, 67, 135-144.

Goulding, K. W. T., Hutsch, B. W., Webster, C. P., Willison, T. W. W., \& Powlson, D. S. (1995). The effect of agriculture on methane oxidation in soil. Philosophical Transactions of the Royal Society of London, 351, 1-14.

Hakanson, L. (1980). An ecological risk index for aquatic pollution control. A sedimentological approach. Water Research, 14, 975-1001.

Harris, M. L., Wilson, L. K., Elliott, J. E., Bishop, C. A., Tomlin, A. D., \& Henning, K. V., (2000). Transfer of DDT and metabolites from fruit orchard soils to American robins (Turdus migratorius) twenty years after agricultural use of DDT in Canada. Archives of Environmental Contamination and Toxicology, 39, 205-220.

Holland, P., \& Solomona, S. (1999). Copper status of orchards. The orchardist, 72,44-45.
Li, Y.L., \& Pu, F. Y. (1992). The mobility of Cu, Pb, Cd and As in agricultural runoff in the area of purple hilly land (in Chinese). Agricultural Environment Protection, 11, 66-71.

Long, P. G. (1983). Notes on pesticides. Department of horticulture and plant health. Palmerston North, New Zealand: Massey University, pp. 95.

Ma, Y. H., \& Liu, S. Y. (1998). Environmental pedology (in Chinese). (pp 178-207). Xi' an: Shanxi Science and Technology Press.

Ma, M., Wang, Z., \& Anders, S. (2001). Contamination of PCBs and organochlorinated pesticides in the sediment samples of Guanting Reservoir and Yongding River (in Chinese). Environmental Chemistry, 20, 238-243.

Merrington, G., Rogers, S. L., \& Van, Z. L. (2002). The potential impact of long-term copper fungicide usage on soil microbial biomass and microbial activity in an avocado orchard. Australian Journal Soil Research, 40, 749759.

Merry, R. H., Tiller, K. G., \& Alston, A. M. (1983). Accumulation of copper, lead and arsenic in some Australian orchard soils. Australian Journal of Scientific Research, 21, 549-61.

Merry, R. H., Tiller, K. G., \& Alston, A. M. (1986). The effects of soil contamination with copper, lead and arsenic on the growth and composition of plants. Plant Soil, 95, 255269.

Merwin, I., Pruyne, P. T., Ebel, J. G., Manzell, K. L., \& Lisk, D. J., (1994). Persistence, phytotoxicity and management of arsenic, lead and mercury residues in old orchard soils of New York State. Chemosphere, 29, 1361-1367.

Nicholson, F. A., Smith, S. R., Alloway, B. J., Carlton-Smith, C., \& Chambers, B. J. (2003). An inventory of heavy metals inputs to agricultural soils in England and Wales. The Science of the Total Environment, 311, 205-219.

NSWEPA, (1995). Orchard and market garden contamination. New South Wales. Lower Hutt, New Zealand Environmental Protection Agency. Available at: http://www.epa.nsw.gov.au/mao/ orchardcontamination.htm. Date accessed 29.09.04.

OLGGWP (Office of Leading Group for Guanting Water Protection). (1977). The study of Guanting water protection (A summary of research results in 1973-1975) (in Chinese). Beijing: China Water Resources and Hydropower Press.

Pinay, G., Fabre, A., Vervier, P., \& Gazelle, F. (1992). Control of $\mathrm{C}, \mathrm{N}, \mathrm{P}$ distribution in soils of riparian forests. Landscape Ecology, 6, 121-132.

Ross, S. M. (1994). Sources and forms of potentially toxic metals in soil plant systems. In S. M. Ross (Ed.), Toxic metals in soil plant system (pp. 3-25). Chichester: Wiley.

Singh, B. R., \& Steinnes, E. (1994). Soil and water contamination by heavy metals. In: R. Lal \& A. Stewart (Eds.), Soil processes and water quality. Advances in soil science (pp. 233-271). Boca Raton, Florida: Lewis.

Sun, F., \& Hao, F. F. (2004). The study of non-point pollution loadings around Guanting Reservoir based on GIS (in Chinese). Beijing Water Conservancy, 1, 16-18.

Sverdrup, H., Warfvinge, P., Blake, L., \& Goulding, K. W. T. (1995). Modeling recent and historic soil data from the Rothamsted Experimental Station, England, using SAFE. Agriculture Ecosystems \& Environment, 53, 161-177. 
Taylor, M. D. (1997). Accumulation of cadmium derived from fertilizers in New Zealand Soil. The Science of the Total Environment, 208, 123-126.

Taylor, M. D., \& Percival, H. J. (2001). Cadmium in soil solutions from a transect of soils away from a fertiliser bin. Environmental Pollution, 113, 35-40.

USEPA (United States Environmental Protection Agency) (1996). Method 3050B: Acid digestion of sediments, sludges and soils (revision 2).

Van-Gaans, P. F. M., Vriend, S. P., Bleyerveld, S., Schrage, G., \& Vos, A. (1995) Assessing environmental soil quality in rural areas. A baseline study in the Province of Zeeland, The Netherlands and reflections on soil monitoring network designs. Environmental Monitoring and Assessment, 34, 73-102.

Wang, H. X. (2000). Pollution ecology (in Chinese). Beijing: Higher Education Press, pp. 188-213.

Wang, X. T., Chu, S. G., \& Xu, X. B. (2003). Organochlorine pesticide residues in water from Guanting Reservoir and Yongding River, China. Bulletin of Environmental Contamination and Toxicology, 70, 351-358.
Webber, M. D., \& Wang, C., (1995). Industrial organic compounds in selected Canadian soils. Canadian Journal of Soil Science, 75, 513-524.

Yang, L. L., Mao, R. Z., \& Li, H. J. (2004). Discussion on patterns and techniques of optimum utilization of water and land in Huailai County (in Chinese). Research of Soil and Water Conservation, 11, 27-30.

Zheng, Y. M., Chen, T. B., \& Chen, H., et al. (2005b). Lead accumulation in soils under different land use in Beijing City. Acta Geographical Sinica, 60, 791-797.

Zheng, Y. M., Chen, T. B., \& Zheng, G. D., et al. (2005a). Chromium and nickel accumulations in soils under different land use (in Chinese). Resources Science, 27, 162-166.

Zheng, Y. M., Chen, T. B., \& Zheng, G. D., et al. (2005d). Copper accumulation in soils under differential land use in Beijing (in Chinese). Journal of Natural Resources, 20, 690-696.

Zheng, Y. M., Luo, J. F., \& Chen, T. B., et al. (2005c). Cadmium accumulation in soils under differential land use in Beijing (in Chinese). Geographical Research, 24, 542548 . 